Relations industrielles

Industrial Relations

\title{
Levine, Gil, editor, Patrick Lenihan: From Irish Rebel to Founder of Canadian Public Sector Unionism
}

\section{Stan Marshall}

Volume 55, numéro 3, 2000

URI : https://id.erudit.org/iderudit/051341ar

DOI : https://doi.org/10.7202/051341ar

Aller au sommaire du numéro

Éditeur(s)

Département des relations industrielles de l'Université Laval

ISSN

0034-379X (imprimé)

1703-8138 (numérique)

Découvrir la revue

Citer ce compte rendu

Marshall, S. (2000). Compte rendu de [Levine, Gil, editor, Patrick Lenihan: From Irish Rebel to Founder of Canadian Public Sector Unionism]. Relations industrielles / Industrial Relations, 55(3), 549-551.

https://doi.org/10.7202/051341ar

Tous droits réservés @ C Département des relations industrielles de l'Université Laval, 2000
Ce document est protégé par la loi sur le droit d'auteur. L'utilisation des services d'Érudit (y compris la reproduction) est assujettie à sa politique d'utilisation que vous pouvez consulter en ligne.

https://apropos.erudit.org/fr/usagers/politique-dutilisation/ 
atteints. De façon plus particulière, pour reprendre les propos de Gérald Larose, ci-devant président de la CSN, les actes de ce colloque permettent de découvrir que la CSN a toujours été un mouvement, lequel s'est déplacé sur les plans idéologique, politique, géographique au fil des ans, et lequel a épousé le chemin parcouru par le peuple québécois. Les textes reflètent également les débats qui ont cours actuellement dans la Centrale (et dans les autres organisations syndicales), en particulier sur les grands enjeux stratégiques des années 2000 et sur les orientations à donner à l'action syndicale.
En somme, l'ouvrage, malgré les lacunes inhérentes à ce genre, peut être utile à tous ceux - professeurs, chercheurs, étudiants, militants, intellectuels - qui s'intéressent à l'histoire de l'un des courants du mouvement syndical québécois, voire même à l'histoire du Québec et surtout, peut-être, à l'histoire de l'évolution des processus de démocratisation des sociétés.

Gilles Ferland Sainte-Mélanie, Québec

\section{Patrick Lenihan: From Irish Rebel to Founder of Canadian Public Sector Unionism \\ edited by Gil Levine, St. John's, Newfoundland: Canadian Committee on Labour History, 1998, 203 p., ISBN 1-894000-00-5.}

At a time when the Canadian labour movement seems intent on splitting into quarrelling jurisdictional factions, it is ironic to read of a man who spent a large part of his life trying to unite workers into a cohesive labour movement representing the interests of workers in both the public and private sectors. But that's what Patrick Lenihan and others were successful in doing and editor Gil Levine has allowed Lenihan to tell this story in his own words.

The current internecine warfare between the Canadian Auto Workers (CAW) and the rest of the affiliates of the Canadian Labour Congress stands in sharp contrast to the battles Lenihan and his contemporaries fought to establish public sector unionism as an integral part of a united house of labour.

Lofty goals of forming a national public sector union and uniting the two major factions within the Canadian labour movement must have seemed daunting just after the Second World war. But the time was right. Public sector workers were ready to embrace unionism and public sector employers were all too willing to sit down and negotiate with their unions. Civic employees were mobilized and energized by activists like Lenihan who were able to win substantial gains at the bargaining tables and in grievance settlements.

While civic employees' unions often have a long individual histories and many were members of the Trades and Labour Congress (TLC), it was not until the 1950 s that they made their presence felt. Before then, in Lenihan.'s words, "the civic employee unions within the TLC were always regarded by the industrial unions as second-class citizens." Activists such as Lenihan realized that civic employees were isolated in their unions with no common organizational bond to further their interests. They set out to correct that by trying to forge a national union for public employees.

In 1952 they convinced the TLC officers to issue a charter for a National Federation of Public Employees as a first step to forming a national union and in 1953 the 12,000 member organization was given the right to charter locals. In 1954 the National Union of Public Employees (NUPE) was formed. NUPE 
formally affiliated to the TLC in 1955 with 23,000 members and a large unorganized public sector waiting to be mobilized.

In the meantime the 10,000 member National Union of Public Sector Employees (NUPSE), an affiliate of the TLC rival Canadian Congress of Labour (CCL), were also active. In hindsight the natural alliance of the two unions and indeed the two congresses was inevitable. The CLC and the TLC did merge in 1956 but it took another seven years for the marriage of NUPE and NUPSE to be consummated as the formation of what is still known as the Canadian Union of Public Employees (CUPE).

Now, at the turn of the century, the labour movement seems to be on the verge of imploding. What is different now from then? Interestingly, Lenihan's story provides some insights.

A twenty-year old Lenihan brought his militant Irish background with him to Toronto in 1923 where a variety of jobs contributed to his continuing militancy. Lenihan chronicles his geographical movement across Canada to Alberta and B.C. and his ideological movement to the Communist Party. Lenihan worked tirelessly for the Party and found himself both revered by those he spoke to and feared by those in power. The consequences were severe for Lenihan internment during the Second World War and left without a job when he and the Party finally parted ways over his drinking escapades.

Still the social and economic conditions were ripe for both the rise of communism as a political alternative to the working and living conditions of the working class and for trade unionism as the collective bargaining alternative for improving workers pay, benefits and working conditions. When Lenihan found himself outside of the Party and within the working ranks he applied the same dedication to unionism as he did to the political doctrine of Communism.
And he did it within the sphere of a large (and growing) untapped reservoir of public sector workers.

The phenomenal growth of public sector unionism after the Second World War and the creation of national unions for civic employees marked a coming of age for public sector workers. Today, the largest union in Canada is a public sector union (CUPE with 485,000 members) and union density within the public sector is greater than that of any other sector. And the turmoil in the labour movement is still centred in the public sector as the CAW stands guilty of raiding public sector workers within the jurisdiction of the Service Employees International Union (SEIU).

However, unlike in Lenihan's day, the turmoil is not the positive bubbling of demands from civic employees to claim their rightful place within the labour movement. Rather it is an internal battle for the hearts and minds of public sector workers within the labour movement. With the CAW wishing to break free of any constraints on organizing protocols established by the CLC, the labour movement is once again at a watershed. The work of Patrick Lenihan and others to build a united labour movement inclusive of pubic sector workers is now threatened as the CAW ponders its own goal to establish a labour central in competition with the CLC and a new political arrangement in competition with the New Democratic Party.

One wonders what Lenihan would think. He himself reconciled his Communist Party past with his activism within a mainstream labour movement and with the creation of the Canadian Commonwealth Federation (CCF) and its successor the NDP. Some would probably say he sold out. Others hold him up as a working class leader with a vision for public sector unionism. Lenihan himself acknowledges that the CCF-NDP was not a radical party when he joined them and would never be. $\mathrm{He}$ 
recognized them for what they were and would stay - a party dedicated to reform but not to socialism. But Lenihan knew there was no other option and strove to implement political and trade union reforms that changed the landscape in a very positive way for workers across Canada.

But the challenge for the labour movement now is to decide whether the vision for reform rests within the existing labour and political alliances or within a new breakaway labour central and an alternative political strategy espoused by an industrial union with aspirations to increase its public sector membership.

What would Patrick Lenihan think? He certainly would be saddened by a possible dissolution of the labour central and the wedge that is being driven between public sector workers. But one thing that is clear from this book is that you have to be close to the action in order to have a vision for the future.

Editor Gil Levine has done a great job of capturing Lenihan's life in his own words so that we can be as close as possible to being in Lenihan's shoes as he made decisions about his own political and trade union life. Those decisions helped shape our world today. It may take another book fifty years from now to detail the inner workings of the labour movement in 2000 in order to assess whether current machinations within the labour movement are vision or folly.

Stan Marshall Canadian Union of Public Employees

\section{La contestation pragmatique dans le syndicalisme autonome : la question du modèle SUD-PTT}

par Ivan SaInSAUlieu, Paris : L'Harmattan, Collection Logiques Sociales, 1999, 287 p., ISBN 2-7384-7616-3.

Pendant longtemps l'approche de la question syndicale en France s'est résumée au traitement des orientations stratégiques des cinq organisations confédérées décrétées représentatives par le pouvoir politique - Confédération générale du travail (CGT), Confédération française démocratique du travail (CFDT), Force ouvrière (FO), Confédération française des travailleurs chrétiens (CFTC), Confédération générale des cadres (CGC) - , auxquelles un regard déjà plus spécialisé ajoutait la Fédération de l'éducation nationale (FEN). Or, ces quinze dernières années, dans le cadre plus général d'une crise de la représentativité politique et sociale, toutes ces organisations ont été de plus en plus contestées dans leur droit à conserver l'exclusivité pour parler, agir et négocier au nom de tous les travailleurs salariés.

De l'émergence des coordinations comme forme d'organisation de la lutte sociale (1986) au développement d'un mouvement associatif diversifié autour de questions de société (1994), plus ou moins négligées par l'action syndicale confédérée comme le logement, le chômage et l'immigration, les espaces sont nombreux pour l'expression d'un syndicalisme autonome lui-même en recherche d'identité. C'est à l'exploration de cette réalité toujours très actuelle que nous convie l'ouvrage politologique d'Ivan Sainsaulieu. Il est essentiel de préciser le parti pris disciplinaire de l'auteur car celui-ci détermine une problématique et un cheminement spécifique autour de l'enjeu étudié. En effet, dès son introduction, l'auteur situe son analyse au cœur des catégories de pensée et des outils du politologue qui, face à des formes institutionnelles, cherche à les qualifier à travers le prisme binaire de l'étude de plusieurs dyades, telles réforme-révolution, confédéréautonome, politique-apolitique. Dans ce cadre, l'objet du livre vise à établir la nature du nouveau syndicalisme 